\title{
SOOME-UGRI VAHETUSÜLIÕPILASED JA -ÕPPEJÕUD 1930. AASTATEL
}

\author{
ENN ERNITS
}

\begin{abstract}
Annotatsioon. Kirjutises käsitletakse 1930. aastate Eesti vahetusüliõpilasi ja -õppejõude, kes omandasid teadmisi või töötasid Ungaris, ning Ungari vahetusüliõpilasi, kes täiendasid end Eestis. Sissejuhatavalt võetakse vaatluse alla 1930. aastal Tartu ülikooli juurde loodud Soome-Ugri Uurimiste Eesti Komitee, mis tegeles peamiselt üliõpilaste ja õppejõudude vahetuse organiseerimisega. Nii Eestis kui ka Ungaris viibis üheksa vahetusüliõpilast, kelle hulgas leidub mitmeid hiljem laiemalt tuntuks saanud teadlasi. Arhiiviainestikule tuginedes käsitletakse nende tegevust võõrsil. Kirjanduse põhjal jälgitakse lühidalt ka nende ettevõtmisi ülikoolijärgsel ajal, pöörates seejuures eriti tähelepanu saavutustele Ungari-Eesti kultuurisuhete arendamise vallas. Suure panuse kultuuri vahendamisel andis enne Teist maailmasõda ungari kirjandust eesti keelde tõlkides Felix Oinas, kes töötas Ungaris ka eesti keele lektorina, pärast sõda aga veelgi olulisemal määral Paula Palmeos, kes tegutses 45 aastat ungari keele õppejõuna, tõlkijana ning tõlkijate ja õppejõudude koolitajana. Alo Raun õpetas ungari keelt ja kirjandust ning uuris hungaroloogilisi küsimusi. Stipendiaatidest on eesti kirjandust ungari keelde vahendanud Béla Kálmán ja Ödön Lavotha. Viimane neist õpetas Ungaris ka eesti keelt. Jószef Györke ja Jenő Fazekas töötasid Tartu ülikoolis ungari keele lektoritena. Vahetusprofessoritena viibisid Ungaris Tartu ülikooli professorid Andrus Saareste ja Julius Mägiste. Üliõpilaste ja õppejõudude vahetus avaldas soodsat mõju rahvusteaduste, eriti soome-ugri keeleteaduse arengule, hõimuaate süvendamisele ja kultuurikontaktide avardamisele.
\end{abstract}

Võtmesõnad: rahvusteaduste ajalugu, soome-ugri keeleteaduse ajalugu, Tartu ülikooli ajalugu, Ungari-Eesti kultuurikontaktid, hõimuliikumine

\section{Sissejuhatuseks Soome-Ugri Uurimiste Eesti Komiteest}

Pärast Eesti Vabariigi rajamist loodi Tartu ülikoolis rahvusteaduste õpetamiseks ja uurimiseks vajalikud institutsioonid, mis meil seni puudusid. Tehti jõupingutusi hõimuliikumise hoogustamiseks. Sidemetele sugulasrahvastega pöörasid suurt tähelepanu sihtasutus Fenno-Ugria, 
Emakeele Selts ja Akadeemiline Hõimuklubi; hoogsa tegevuse eelduseks oli kolme iseseisva soome-ugri riigi teke pärast Esimest maailmasõda (Prozes 2012: 104-105). Peale mainitud asutuste-seltside tegutses aastail 1930-1940 Tartu ülikooli juures Soome-Ugri Uurimiste Eesti Komitee (SUU EK), millel oli sõsarkomiteed Ungaris ja Soomes. SUU EK avaldas toimet rahvusteaduste arengusse ja hõimuliikumisse üliõpilaste ja õppejõudude vahetuse korraldamise kaudu. Komitee ajalugu pole teadaolevalt seni käsitletud.

SUU EK asutati 29. septembril 1930 Eesti Rahva Muuseumi ruumis (Tartu, Aia 42, praegune Eesti Kirjandusmuuseumi maja) toimunud koosolekul. Arutelust võtsid peale haridus- ja sotsiaalministri Jaan Hünersoni, haridus- ja sotsiaalministeeriumi (Hasomin) teaduse ja kunstiosakonna direktori Gottlieb Ney ja Tartu ülikooli rektori Johan Kõpu osa ka peamised rahvusteaduste viljelejad: professorid Julius Mark (Uurali keeled), Andrus Saareste (eesti keel), Julius Mägiste (läänemeresoome keeled), Harri Moora (arheoloogia), Eesti Rahva Muuseumi direktor Ferdinand Leinbock (hilisema nimega Linnus; etnograafia) ja Eesti Rahvaluule Arhiivi juhataja Oskar Loorits (rahvaluule). Üritusel osales ka ungarlasest administratiivõiguse professor, Ungari teadusliku instituudi juhataja István (Stefan) von Csekey. Koosoleku ohjad olid J. Hünersoni käes, protokollis O. Loorits (1: $1 \mathrm{jj}){ }^{1}$

Ungari haridusministeerium oli teinud Eesti Hasominile ettepaneku luua soomeugriliste uurimiste Eesti rahvuslik komitee, mis tegutseks käsikäes samasuguste institutsioonidega Ungaris ja Soomes. Selleks pidas 1930. aasta kevadel Eestis ja Soomes läbirääkimisi Ungari haridusminister krahv Kuno von Klebelsberg. Ungari haridusministeerium oli asutanud kaks stipendiumi: üks neist (100 dollarit) eriteadlasele, kes professori või lektorina peaks mõnes Ungari ülikoolis loenguid, teine aga mõnele eesti üliõpilasele õppimiseks kas József Eötvösi kolledžis, Tihanyi bioloogiainstituudis või Ungari kolledžis Roomas.

Gottlieb Ney soovitas panna komiteele nimeks soome-ugri uurimiste komitee Eestis. Hasomin oli koostanud selle põhikirja esialgse kava. Julius Margi teatel olevat esialgu olnud kavas luua kolmes hõimuriigis kaks eraldiseisvat asutust: 1) soome-ugri uurimiste instituut, mille üles-

${ }^{1}$ Ruumi kokkuhoiu ja parema loetavuse huvides on käesolevas kirjutises ära jäetud pidevalt korduvad fondi ja nimistu number (f 3699, n 1). Viidatud pole internetist saadud info allikaid isikute surmaaja ja avaldatud teoste kohta. 
andeks saanuks uurimistöö korraldamine ja tegemine, ning 2) komitee, mis tegeleks koostöö reguleerimisega. Ent Hasomini koostatud põhikirja kavandis liideti mõlema institutsiooni ülesanded ühte. Seda ei pidanud J. Mark muide soovitavaks. Instituudi asutamist oli juba arutatud varem, nimelt sama aasta kevadel rektor Johan Kõpu algatusel.

Koosolekul arutati tulevase komitee põhiülesandeid ka konkreetsemalt. Andrus Saareste arvates võinuks komitee olla ,uurimistöö nii-öelda üldpoliitika juhtijaks", st koordineerijaks. Põhimõtteliselt sama toonitas ka Julius Mägiste. Seevastu Julius Mark pidas esmatähtsaks ühistööd väljaspool Eestit koos Ungari ja Soome komiteega. Ta lähtus soome-ugri instituudi loomise eeldusest: viimane koordineeriks Eestis tehtavat uurimistööd, komitee aga kolmes hõimuriigis tehtavat. Sõnavõtja eeldas, et üheks komitee ülesandeks jääks teadlaste ja üliõpilaste vahetus. Harri Moora lisas, et akadeemiliste seltside koordineerimise kogemus olevat meil juba Õpetatud Eesti Seltsi näol olemas. Minister rõhutas omalt poolt, et komitee ei saa mõjuda niivõrd administratiivselt kui selle liikmete autoriteedi kaudu.

A. Saareste tõstatas koosolekul küsimuse, kas tulevase komitee koosseisus ei peaks olema ka kirjanduse ja ajaloo esindajaid. Siiski jäädi O. Looritsa seisukoha juurde, mille kohaselt ei tohiks komitee koosneda teatud alade või asutuste esindajatest, vaid esmajoones soome-ugri teadustega viljelevatest isikutest. Väljendati soovi, et komitee tegutseks Tartu ülikooli juures nagu teised sarnased institutsioonid.

Seejärel moodustati komitee, mille liikmeteks said J. Mark, J. Mägiste, A. Saareste, H. Moora, F. Leinbock ja O. Loorits. Esimeheks valiti J. Mark ja sekretäriks O. Loorits. J. Mark jäigi SUU EK esimeheks kogu selle eksisteerimisaja vältel, sekretäriks sai 1933. aastal F. Leinbock. 19.-24. septembril 1931 toimus Helsingis soome-ugri komiteede esindajate nõupidamine, millel osales Eestist J. Mark (1: 12).

Järgmisel komitee koosolekul, mis toimus 14. detsembril 1930 samas kohas kus asutamiskoosolek, viimistleti esimehe ja sekretäri esitatud põhikirja kavandit. Selles fikseeriti, et SUU EK põhieesmärk on edendada koos samalaadsete komiteedega Soomes ja Ungaris soome-ugri rahvaste kultuuri uurimist rahvusteaduste, nimelt keeleteaduse, ajaloo ja kultuuriloo, arheoloogia, etnograafia ja rahvaluule vallas. Komitee ülesanded olid põhikirja järgi: 1) kontakti pidamine Ungari ja Soome komiteega, 2) vastastikku informeerimine tehtavast uurimistööst ning kirjanduse ja info vahendamine, 3) välismaale saadetavate kandidaatide 
valimine üliõpilaste ja teadlaste seast ning neile materiaalsete vahendite hankimine Hasominilt, Kultuurkapitalilt jm, 4) arvamuste avaldamine teadlaste sobivuse kohta välismaale lähetamiseks ning 5) oma eelarve koostamine ja kontroll selle summade kasutamise kohta. Lahtiseks jäeti küsimus, kas komitee ülesannete hulka tuleks lisada ka kogumis-, korraldus- ja uurimistöö algatamine, toetamine ja ühtlustamine Eestis. SUU EK moodustati personaalsetel alustel, st liikmed hakkasid eespool nimetatud rahvusteaduste arengu eest vastutama oma eriala järgi. Põhikirja ülejäänud paragrahvid puudutasid komitee tegevuse praktilisi aspekte, millest ehk huvipakkuvam on see, et plaaniti vaid kaks korralist koosolekut aastas.

Kavatsetud ülesanded osutusid SUU EK-le üle jõu käivateks ning jäid enamasti täitmata. Komitee põhitööks oli sobivate stipendiaatide väljasõelumine ja neile raha muretsemine, seega Eesti vahetusüliõpilaste ja -õppejõudude Ungarisse lähetamine ja Ungari vahetusüliõpilaste vastuvõtmine. Juba asutaval koosolekul tundis H. Moora muret uue institutsiooni rahaallikate pärast. Haridusminister rahustas teda väitega, et raha eraldatakse kas Eesti Kultuurkapitali või eelarve kaudu, nimelt olevat Hasomin lisanud eelarvesse ühe stipendiumi jagu raha mõnele hõimurahva üliõpilasele, kuid teadlaste vahetust saaks esialgu teha ainult Tartu ülikooli ungari keele lektori ametisse seadmisega mõne noorema Ungari uurija Eestisse kutsumise teel. Ungari saadikult oli juba saadud teade ühe stipendiumi asutamise kohta Eesti üliõpilasele Ungaris (1: 3).

1931. aastaks taotleti raha Hasominilt järgmisel määral: 400 krooni stipendiumi Ungaris õppimiseks, $180 \mathrm{kr}$ ungari keele lektori toetuseks, 120 kr komiteede nõupidamise kuludeks ning 80 kr asjaajamiseks ja muudeks kuludeks (1: 11). Peatselt selgus, et ungari keele lektorile polnud vaja maksta lisatoetust, sest ta sai seda enda kodumaalt (1: 12). Järgmistel aastatel pidi SUU EK raha taotlema Eesti Kultuurkapitalilt. Seda ka saadi, ent aastatel 1939-1940 enam mitte, sest Eesti ja Ungari vahelise kultuurikonventsiooni kehtima hakkamise järel 1937. aastal hakati stipendiumi maksma riigi eelarvest $(1: 40 \mathrm{p}-41 ; 2: 8)$.

\section{Eesti üliõpilasstipendiaadid Ungaris}

SUU EK valis sobivad stipendiumikandidaadid sooviavalduste põhjal rahvusteadusi õppivate üliõpilaste või ülikoolihariduse omandanute seast. Kandideerijatelt nõuti mõningast ungari keele oskust. 1938. aastal otsus- 
tas SUU EK hakata kontrollima, kas Ungarisse sõitvate stipendiaatide kandidaadid ungari keelt valdavad. See ülesanne anti prof J. Margile (1: 36p-37). Enamik stipendiaate õppis Ungaris ühe õppeaasta. Stipendiumi maksis Ungari haridusministeerium. Stipendium hõlmas sõitu Tartust Budapesti ja tagasi, priid ülalpidamist ja taskuraha (nt 25 pengöt 1938. aastal) ning eraldi rahasummat ka Ungari riigiga tutvumiseks. Eesti maksis omalt poolt $200-300$ krooni lisatoetust $(2: 17,36,55)$. Ungaris viibis aastatel 1931-1940 üheksa Tartu ülikooli inimest (tabel 1).

Tabel 1. Eesti stipendiaadid Ungaris

\begin{tabular}{|l|l|}
\hline Aastad & Vahetusüliõpilane \\
\hline $1931-1932$ & Aleksei Reisman \\
\hline 1932 (üks semester) & Vassili Noot \\
\hline $1933-1934$ & Gustav Must \\
\hline $1934-1935$ & Leela Topman \\
\hline $1935-1936$ & Felix Johannes Oinas \\
\hline $1936-1937$ & Pauline Palmeos \\
\hline $1937-1938$ & Õie Olup-Sõster \\
\hline $1938-1939$ & Juhan Viiret \\
\hline $1939-1940$ & Aino Undla \\
\hline
\end{tabular}

Esimesena sai Ungaris õppimise stipendiumi 7-8 kuuks 1931. aastal Tartu ülikooli üliõpilane Aleksei Reisman, meile tuntud nimega A1o R a u n (1905-2004; 3: 67; AA II: 319-320). Budapestis Péter Pázmányi ülikoolis kuulas ta tuntud ungari keeleteadlaste Zoltán Gomboczi, Gyula Némethi ja Miklós Zsirai loenguid. ${ }^{2}$ A. Raun viibis Ungaris ka 1932.-1933. õppeaastal, ent see ei kajastu SUU EK dokumentides. Sellal kogus ta oma võrdlusastmete-teemalise doktoriväitekirja jaoks andmeid ungari vana kirjakeele ja murrete kohta (Alvre 1990: 197-198).

A. Raunast kujunes rahvusvaheliselt tuntud õppejõud ja teadlane, kes on avaldanud uurimusi üldkeeleteaduse, soome-ugri ja türgi-tatari keelte alalt. Ungaris saadud impulsse ja teadmisi kasutas ta mitmeti nii Euroopas kui ka Ameerikas, õpetades ungari keelt, ungari keele ajalugu ja ungari kirjandust ning uurides ugri keeli, eriti neist ungari keelt (Alvre 1990:

2 Seda nime kandis 1921. aastani Budapesti ülikoolina tuntud, praegune Loránd Eötvösi ülikool aastatel 1921-1950. József Eötvösi kolledž, mis koolitas peamiselt õppejõude, kuulus selle alla. 
$198 \mathrm{jj}$ ). Edaspidi tuleks selgitada, kas turkoloogia harrastamine sai alguse samuti Ungarist, kus seda teadusharu on kaua viljeldud.

Teisena täiendas end Budapestis soome-ugri keeleteaduse alal Va s sili (Vassel) N o ot (1906-1951). Kuna ta ungari keele oskus oli veel kasin, siis kulus enamik ajast selle omandamisele. Siiski osales ta oma sõnutsi ka õppetöös ning töötas läbi uurimuseks „Ungari, soome ja eesti keele esimese silbi vokalism võrdlevalt" vajalikud kirjandusallikad (1: 12; 3: 66). V. Noot lõpetas Tartu ülikooli 1934. aastal kiitusega, töötas seejärel Saaremaal koolinõunikuna ja siirdus pärast Teist maailmasõda Saksamaa kaudu Inglismaale (AA II 397).

Üliõpilane Gustav Must (1908-1991), kelle peaaineks Tartu ülikoolis oli eesti keel, kulutas samuti valdava aja Ungaris viibides keeleõpingutele. Seepärast luges ta seal igasugust kirjasõna, eriti ajalehti, käis teatrietendustel, kontsertidel, muuseumides jm ning ostis endale ungarikeelset kirjandust. Ta kuulas Z. Gombocsi, M. Zsirai, János Melichi, János Horváthi jt loenguid. Järjekindlalt osales ta sealse keeleteadusseltsi ja Ungari teaduste akadeemia koosolekutel, samuti keeleteadlaste ringi Kruzsok iganädalastel kooskäimistel. Eesti Vabariigi aastapäevapeol pidas G. Must ungarikeelse kõne Eesti saavutustest ning avaldas Ungari peaministri Gyula Gömbösi Roomas käigu puhul ajalehe Vaba Maa juhtkirjas ülevaate Ungari välispoliitikast ja suhetest teiste Kesk-Euroopa riikidega. Jõulude ja lihavõttepühade ajal viibis stipendiaat mõlemal korral Ungaris kuskil maapiirkonnas ning käis kevadel Balatoni järve ääres, Pécsis, Szegedis jm (3: 51, 64).

G. Must õppis Tartu ülikooli filosoofiateaduskonnas aastatel 19291938 ja lõpetas selle kiitusega. 1949. aastal kaitses ta Göttingeni ülikoolis doktoriväitekirja „Germaani keelte mõjust eesti ja soome meremeestekeele sõnavarale". Temast sai Ameerikas emigrandina elades saksa keele ja kirjanduse professor. G. Musta uurimused käsitlevad peamiselt saksa keelt ja võrdlevat keeleteadust, samuti varakeskaegseid käsikirju (AA III: 22). Tal on peale doktoridissertatsiooni ka muid, peamiselt germaani keeltega seonduvaid uurimusi läänemeresoome keelte vallast, sh kirjutisi Revali nimest, laev- ja leib-sõna etümoloogiast, inglise algupäraga raudteeterminoloogiast jm (ETBL: 657-658). Tema hilisemate seoste kohta ungari keele ja kultuuriga pole andmeid.

Ka L e e la To pman (1911-1993), kes oli lõpetanud Tartu ülikooli eesti keele alal ja tahtis jätkata uurali keeleteaduse vallas, kuulas keele- 
loenguid P. Pázmányi ülikoolis ning viibis mitmes paigas, sh kolm nädalat Szegedis ja kaks nädalat Debrecenis. Ungari haridusministeeriumi toel käis ta Viini Ungari kolledžis $(2: 41 ; 3: 41,59)$. L. Topman lõpetas Tartu ülikooli filosoofiateaduskonna kiitusega nii 1934. kui ka 1937. aastal. Keeleteaduse vallas ta tuntuks ei saanud, küll aga pedagoogina. 1960. aastatel töötas Topman Eestis kooliinspektorina (AA II: 515).

Suhteliselt põhjaliku aruande Ungaris õppimise kohta koostas üliõpilane Felix Johannes O inas (1911-2004). Ta õppis Tartu ülikoolis eesti keelt, läänemeresoome ja uurali keeleteadust, kirjandust ja rahvaluulet. Stipendiaat kuulas P. Pázmányi ülikoolis peamiselt M. Zsirai loenguid ja osales ta seminariharjutustel. Huvi pakkusid ka Gy. Némethi loengukursus „Ungari ja Türgi kokkupuuteist”, prof J. Horváthi ja prof Elemér Császári loengud ungari kirjandusloost ning prof Elemér Mályuszi loengud Ungari ajaloost. F. Oinas, kel oli enne Ungarisse saabumist Tartu ülikooli ungari keele lektorite toel omandatud passiivne ungari keele oskus, õppis Ungaris viibides seda keelt korralikult valdama. Prof A. Saareste Ungarist lahkumise järel õpetas ta 1936. aasta veebruari keskpaigast kuni kevadeni kaks tundi nädalas eesti keelt. Eelmise, 1935. aasta sügisel oli ta kirjutanud valmis Tartu ülikooli auhinnatöö, pärastise magistritöö „Hilistekkinud käänded läänemeresoome keeltes".

Noor stipendiaat aitas Ungaris õppides igati kaasa Ungari-Eesti kultuurisuhete süvendamisele. Ta tõlkis ungari keelest Lajos Zilahy romaani „Kaks vangi” („Két fogoly”) esimese osa, mis ilmus Tartus Noor-Eesti kirjastuses 1936. aastal. Ta avaldas Ungari kohta ajalehes Postimees kuus tutvustavat artiklit. F. Oinas tegi tutvust Ungari kooliolude ja Eesti-Ungari suhete ajalooga, millest kirjutas perioodikas, viimati mainitud teemal ka ajakirjas Tänapäev (1936). Kõigele lisaks käis ja elas stipendiaat mitmes paigas Ungaris, sh kümme päeva Pápas ja Szombathelys, viis päeva Dömsödis ning paar nädalat Ida-Ungaris Tiszakerecsenyis ja Debrecenis (3: $33-35,47-48)$.

F. Oinas lõpetas Tartu ülikooli kiitusega 1937. aastal ja kaitses järgmisel aastal eespool nimetatud teemal kirjutatud magistritöö. Budapesti ülikooliga jätkusid töösuhted. Ta õpetas József Eötvösi kolledžis aastatel 1938-1940 esimese ametliku lektorina eesti keelt, samuti pidas loenguid soome-ugri keeltest ja õpetas prof Lauri Kettuneni äraolekul ka soome keelt. F. Oinase mitmekülgseid suhteid Ungariga on põhjalikult vaaginud Liina Sillaots (2000). Tema uurimuse põhjal oli F. Oinase panus eesti 
kultuuri tutvustajana sõjaeelses Ungaris ja ungari kultuuri vahendajana Eestis suur. 1939. aastal avaldas Felix Oinas suurmeeste elulugude sarjas ungarikeelse allikmaterjali põhjal valminud monograafia „Petőfi. Vabaduse ja armastuse laulik”. Ta tõlkis ka L. Zilahy romaani „Kaks vangi” kaks viimast osa $(1937,1938)$, samuti Jószef Nyírő romaani „Mägede mees" (1939). Peale Ungari tutvustamise Eesti ajakirjanduses tutvustas F. Oinas Eestit Ungaris. 1939. aastal hakkas ta koos ungari keele lektori Jenő Fazekasiga koostama suurt ungari-eesti sõnaraamatut, kuid kiiresti muutuvate olude tõttu jäi töö algjärku.

Felix Oinasest sai Teise maailmasõja järel Ameerikas slaavi ja UuraliAltai keelte professor. Ta sai tuntuks eelkõige silmapaistva folkloristina. F. Oinas on uurinud soome-ugri ja slaavi rahvaluulet ning keeli (AA III: 50). Juba vahetusüliõpilasena Ungaris viibides oli ta keskendunud neile distsipliinidele (Oinas 1995: 122).

Järgmise vahetusüliõpilasena täiendas end Budapestis P. Pázmányi ülikoolis P a u l in e (hiljem Paula) P a l m e o s (1911-1990), kes oli Tartus õppinud eesti keelt ja uurali keeleteadust ülemastme, eesti ja maailma (ehk üldist) kirjandust keskastme ning rahvaluulet alamastme ulatuses. Ta kuulas võrdleva keeleteaduse ja ungari kirjanduse loenguid M. Zsirai, E. Császári, J. Horváthi jt juures. Kevadsemestril alustas ta ainestiku kogumist uurimuse „Esimese silbi vokaalid läänemeresoome ja ungari keeles" jaoks. Palmeos oli omandanud ungari keele algteadmised lektor J. Györke juures, täiendas keeleoskust sedavõrd, et suutis peatselt lugeda nii ilu- kui ka teaduskirjandust, sai aru kõnekeelest ning võis ,,suuremate raskusteta juttu ajada". M. Zsirai seminaris pidas ta ungarikeelse ettekande murdeuurimisest Eestis ja ühes kalvinistlikus koguduses loengu Eesti ajaloost ning õpetas Ungari keeleteadusliku seminari liikmetele eesti keelt (3: 22, 38). Ungaris möödunud õpiaastat on P. Palmeos vanuigi kajastanud oma mälestustes (vt Palmeos 1991).

Paula Palmeos lõpetas 1939. aastal Tartu ülikooli kiitusega. Ta omandas järgmisel aastal eelmainitud teemal kaitstud väitekirjaga magistriastme, mis 1949. aastal atesteeriti ümber filoloogiakandidaadi kraadiks. Palmeosest sai kõige tulemuslikum ungarluse viljeleja Eestis. Töötades 45 aastat Tartu ülikooli soome-ugri kateedri õppejõuna, õpetas ta ungari, soome, karjala ja vepsa keelt ning luges peale arvukate muude distsipliinide ungari keele ajaloolist grammatikat (AA III: 40; BN: 234-235). P. Palmeos on tõlkinud Zsigmond Móriczi novellikogu ,Seitse kreutserit” 
(1958), osa muinasjutte Emil Kolozsvár Grandpierre'i muinasjutukogust „Imeflööt” (1959), koostanud, toimetanud ja saatesõnaga varustanud Sándor Petőfi luule valimikud eesti ja läti lugejale ning arvustanud eesti kirjanduse ungari tõlkeid. Nimetatud muinasjutukogu on hiljem üllitatud veel kahel korral $(1981,2006)$. P. Palmeos on põhjalikult tutvustanud eesti ilukirjanduse tõlkeid ungari keelde (Palmeos 1974). Tema õpilastest on kasvanud suurepäraseid ungari kirjanduse tõlkijaid, nt Aino Pervik, Tiiu Kokla, Edvin Hiedel, ning ungari keele õppejõude, nagu Tõnu Seilenthal, Ene Asu-Õunas ja Anu Nurk (Palmeos 1976: 204, 205; Seilenthal 2003: 314). Nõnda tagati ungari keele järjepidev õpetamine üliõpilastele ajani, mil sai taas kutsuda Tartusse ungarlastest keelelektoreid. Paula Palmeos tundis suurt sümpaatiat Ungari vastu. Seal tundis ta end koduselt ja pidas Ungarit oma teiseks kodumaaks (Palmeos 1983: 168).

Samamoodi nagu eelmainitutel kulgesid Ungaris ka filoloogia üliõpilaste Õie Olup-Sõsteri (2: 70; 3: 14, 29-30) ja Juhan Viireti (2: 50; 3: 8, 20-21) õpingud ja ringreis, mille keskel nad omandasid eelkõige aktiivse ungari keele oskuse.

Õ i e Ol u p-Sõ st e r (hiljem Olup-Haas ja Sõster-Haas; 1912-2008) õppis Tartu ülikoolis vaheaegadega tosin aastat (1930-1942), jõudes vahepeal kaks korda mehele minna, kuni viimaks lõpetas kursuse. Enne Ungarisse kandideerimist seati talle eeltingimuseks end uuesti üliõpilaseks registreerida. Õ. Olup-Sõster kuulas Budapestis M. Zsirai, J. Melichi, Gy. Némethi jt loenguid eeskätt soome-ugri keeleteaduse ja kirjanduse vallast. Ta töötas sageli Ungari keeleteadusliku seminari raamatukogus, käis Ungari teaduste akadeemia keeleteadusalastel koosolekutel, nautis populaarteaduslikke loenguid, luges ungarikeelset kirjandust. Stipendiaat käis muuseumides, näitustel, teatris, eriti rahvusteatris, ning võttis aktiivselt osa Ungari-Eesti seltsi üritustest, käis koolides jm korraldatud hõimuüritustel. Suvel rändas ta ringi mööda Ungarit, viibides Balatoni ääres, Keszthelys, Debrecenis, Szegedis ja Pécsis (1: 30-31; 3: 14).

Pärast lühikest töötamist Teise maailmasõja ajal Eesti koolides õpetajana emigreerus Õie Olup-Sõster Saksamaale ja sealt Austraaliasse, kus töötas pikka aega algkooliõpetajana ja seejärel ajalehe Virgats toimetajana (AA III: 45). Õie Sõster-Haasi nime all on ta avaldanud mälestusraamatukese „Narvast Austraaliasse” (Tallinn, 1993) ja Õie Haasi nime all „Kodumaa võõrsil” (Tallinn, 2002). Ta on olnud koguteose „Eestlased Austraalias" esimese osa (Adelaide, 1988) kaasautor ja -toimetaja. 
Üliõpilasena avaldas ta Emakeele Seltsi toimetiste sarjas 12-leheküljelise kirjutise „Teise silbi poolpikk vokaal eesti ühiskeeles”, mis oli tegelikult äratrükk ajakirjast Eesti Keel (1938).

J uh a n Vi iret (1913-1954), kes 1935. aastani kandis nime Johannes Viil, õppis Tartu ülikoolis eesti filoloogiat aastatel 1930-1940 ja jätkas filosoofiateaduskonnas õpinguid veel ühe aasta jooksul (AA III: 77). Budapestis asus ta kohe P. Pázmányi ülikoolis ungari keelt õppima, omandades sama aasta (1938) jõuludeks juba passiivse ja järgmise aasta suveks aktiivse keeleoskuse. Ta kuulas sügissemestril E. Czászári loenguid S. Petőfist, M. Zsirai loenguid soome-ugri häälikuõpetusest, Dezsö Paisi loenguid ungari häälikuloost ja XII sajandi kirjamälestisest „Halotti Beszéd” („Hauakõne”) ning Gy. Némethi loenguid Ungari ajaloost, kevadsemestril aga J. Horváthi loenguid ungari keele vanematest laensõnadest, M. Zsirai loenguid soome-ugri sõnamoodustusest ning soome-ugri ja samojeedi keelesugulusest. Eraldi on J. Viiret märkinud tutvumist XIXXX sajandi mõjukaima lingvisti Zsigmond Simonyi uurimusega ungari keele abisõnadest. Ta luges ungari kirjandust, nii proosat kui ka luulet, ja muretses seal endale 60 teost. Kevadel käis ta Budapesti muuseumides ning juunis viibis õppereisil Kirde-Ungaris Egeris ja Miskolcis (3: 8). Koos lektor Felix Oinasega toimetas J. Viiret Budapesti tehnikaüliõpilaste organisatsiooni Hungaria samanimelise ajalehe Eestit käsitleva ungari-ja eestikeelse erinumbri (Sillaots 2000: 420). Ta abistas F. Oinast „Mägede mehe" tõlkimisel ja retsenseeris 1940. aastal ajakirjas Eesti Kirjandus äsja ilmunud Petőfi-monograafiat (Oinas 1995: 122). Pärast Teist maailmasõda töötas J. Viiret õpetajana Tõrva keskkoolis (Aader 2007).

Peaainena kirjandust õppinud ja 1937. aastal diplomeeritud stipendiaadikandidaat A i no Undla (neiuna Krimm, teises abielus Undla-Põldmäe; 1910-1992) pidi erinevalt keeleüliõpilastest tõlkima $20 \mathrm{lk}$ kergemat ungarikeelset teksti ja suuliselt vastama ungari grammatika aluseid. Budapestis täiendas ta end ungari kirjanduse ja kirjandusteaduse vallas. Peale selle soovis ta Ungaris registreerida Harry Jannsenisse ja selle poolt Budapestis toimetatud ajakirjasse puutuva ainese. ${ }^{3}$ Undla kirjeldas ühes palvekirjas, kuidas tal õnnestus kolme ööpäeva jooksul rongiga sõita Läti, Leedu ja Saksamaa kaudu Budapesti, lisades: „Elu on siin [Budapestis] poliitiliselt vähem närvesööv kui Tartus.” $(1: 37,38 ; 2: 19,29,33)$ Oli

3 Jutt on Lydia Koidula venna Harry Jannseni (1851-1913) poolt Budapestis asutatud ja toimetatud rahvusvahelisest ajakirjast West-östliche Rundschau (vt EKL: 144). 
juba 1939. aasta lõpp! Elukalliduse tõusu tõttu palus ta SUU EK kaudu lisatoetust 200 krooni, mis talle ka määrati (2: 1).

Aino Undla, kes ülikooli kõrval õppis ka Tartu kõrgemas muusikakoolis, täiendas end laulu alal Budapesti Ferenc Liszti nimelises muusikaakadeemias. Lisaharidus võimaldas tal pärast sõda Siberisse küüditatuna teenida elatist muusikaõpetajana. A. Undla on vabakutselise kirjandusteadlasena uurinud XIX sajandi naiskirjanikke, peamiselt Lydia Koidula elu ja luuletusi (AA II: 544-545; EKL: 629).

Eesti keelt ja kirjandust ning läänemeresoome keeli õppinud üliõpilasel Aksella Retsil (abielus Lokk; snd 19184), kelle Ungaris viibimine oli kavandatud 1940.-1941. õppeaastaks, jäi saabunud okupatsioonide tõttu seal ilmselt käimata (1: 40p; 2: 5). A. Rets õppis Tartu ülikooli filosoofiateaduskonnas aastatel 1938-1944. Lõpetamise aastal emigreerus ta Saksamaale, hiljem sealt edasi Inglismaale ja Kanadasse. Toronto ülikoolis õppis ta raamatukogutöötajaks, kellena töötas pikka aega (AA III: 346).

Kõik soovijad ei pääsenud Ungarisse end täiendama. Käsitleme lühidalt neidki. Kandidaatide seas oli Saaremaalt pärit Arnold Miller (1908-1961), kes tahtis minna Ungarisse 1933/1934. õppeaastal. Ta oli prof J. Margi soovitusel saanud soome ja sugulaskeelte professori Niilo Ikola kaudu kutse tulla Turu ülikooli eesti keele õpetajaks ning alustas peatselt sealsamas õpinguid soome-ugri keelte vallas (3: 60-63). Lähetamata jäämise põhjuseks oli ilmselt see, et ta polnud toona Tartu ülikooli üliõpilane. A. Miller oli Tartu ülikoolis õppinud eesti keelt aastatel 1927-1934, seejärel eesti filoloogiat aastatel 1951-1961, kuid õpingud jäid lõpetamata (AA II: 478). Pärast sõda töötas ta EKP Keskkomitee Partei Ajaloo Instituudis marksismi-leninismi klassikute teoste tõlgete sektori juhatajana, tegeldes asjaomase kirjanduse tõlkimise ja toimetamisega (Miller 1961).

A lma Peters on (snd 1904) viibis Budapestis omal algatusel. Ta kavatses seal sooritada statistika, poliitika ja riigiõiguse eksamid, kuid ei suutnud seda ungari keele tagasihoidliku valdamise tõttu. Seepärast palus ta SUU EK vahendusel stipendiumi, et saaks täiendada oma keeleoskust (3: 5). Talle ei võimaldatud seda, kuna ta polnud rahvusteadusi õppiv üliõpilane, vaid oli 1929. aastal lõpetanud Tartu ülikooli kaubanduse erialal (AA II: 322).

4 Kõigil neil, kel on märgitud vaid sünniaasta, on surma-aasta teadmata. Mõni neist võib veel elada, lähemad andmed puuduvad. 
Ungari stipendiaadiks ei pääsenud peamiselt viitele õppinud E r n a Tille man n (abielus Siirak; 1911-1987). Talle eelistati, ja mitte alusetult, Felix Oinast (3: 45). E. Tillemann lõpetas Tartu ülikooli kiitusega 1936. aastal, mil kaitses magistritöö A. H. Tammsaare lauseehitusest. Ta töötas toimetaja, bibliograafi ja kirjandusteadlasena (AA II: 553). Ungarisse ei pääsenud õppima ka Vikt or Ka u dre (1935. aastani Kraut; 1909-1999), kellel Tartu ülikool jäi lõpetamata. Ta emigreerus sõja ajal Rootsi ja sealt Kanadasse (3: 26; AA III: 154). Ungari jäi üliõpilasperioodil nägemata ka L e m b it N i g olil (snd 1915), kes lõpetas kiitusega filosoofiateaduskonna 1940. aastal ja jätkas seal õpinguid sõja ajalgi (3: 11; AA III: 191).

\section{Ungari stipendiaadid Eestis}

Soome-ugri uurimiste Ungari komitee valis igal aastal välja ühe stipendiaadikandidaadi Eestisse saatmiseks, kuid stipendiumi maksis Eesti. Stipendium sisaldas enamasti 160 kr sõiduraha, 80 krooni elatisraha, millega pidi Tartus saama lahedasti ära elada, ning 40-50 kr sõiduraha Eestiga tutvumise kavatsuse korral (1: 22p; 2: 36). Aastatel 1932-1940 käis Eestis end täiendamas ühtekokku üheksa inimest (tabel 2). Paraku pole alles kõigi Tartus käinute aruandeid. Stipendiaatide seas oli nii hiljem laiemalt tuntuks saanud isikuid kui ka teisi.

Tabel 2. Ungari stipendiaadid Eestis

\begin{tabular}{|l|l|}
\hline Aastad & Vahetusüliõpilane \\
\hline 1932 & György Lakó \\
\hline $1932-1933$ & Magda Köves \\
\hline $1933-1934$ & Jenő Fazekas \\
\hline $1934-1935$ & Béla Kálmán \\
\hline $1935-1936$ & Magda Herger \\
\hline $1936-1937$ & Albert Mjazovszky \\
\hline $1937-1938$ & Ödön Lavotha \\
\hline $1938-1939$ & László Kovács \\
\hline $1939-1940$ & János Kajos \\
\hline
\end{tabular}

Professorikutseks valmistuv Gy örgy Lakó (1908-1996) oli pühendunud eesti ja permi keelte uurimisele (2: 120). Ta viibis Eestis 1932. aasta algusest kuni 1. juulini (1: 14). G. Lakóst sai hiljem Loránd Eötvösi 
ülikooli soome-ugri õppetooli professor ja Ungari teaduste akadeemia liige (Forschungsstätten 1975: 155). Ta on uurinud ka saami, ugri jt keeli. G. Lakó on mõnevõrra tõlkinud ka eesti kirjandust ungari keelde (Bereczki 2011: 278). 1985. aastal avaldas G. Lakó saksa keeles kirjutise „Eesti keele osast soome-ugri keelesuguluse tõestamisel ning Ungari-Eesti kultuurisidemete algusest".

Magda Köves (abielus Köves-Andrássy; 1910-1992), kes viibis Tartus 1932.-1933. õppeaastal, töötas hiljem Debreceni Lajos Kossuthi ülikooli soome-ugri õppetooli dotsendina. Ta on uurinud soome-ugri aluskeele morfoloogiat, soome keelt, permi keeli jm (Forschungsstätten 1975: 155).

Jenő Fazekase (1906-1979) peateeneks peetakse XIX sajandi Iõpul hantide juures käinud ungari teadlase József Pápay kogutud tekstide publitseerimist (Seilenthal 2003: 311). Ta kuulas Tartu ülikoolis J. Margi ja J. Mägiste loenguid ning jälgis Eesti Keele Arhiivi ja Eesti Rahvaluule Arhiivi tööd. Samuti tutvus ta pikemal reisil Lõuna-, Lääne- ja Põhja-Eesti vaatamisväärsustega (3: 55). J. Fazekas vahendas 1935. aastal Ungaris eesti keelekorralduslikke ja -uuenduslikke pürgimusi ja andis 1938. aasta ajakirjas Looming ülevaate uuemast ungari kirjandusest. Järgmisel aastal ilmus „Varamu” sarjas ta raamat „Ungarlus ja Euroopa kultuur”. J. Fazekas töötas Teise maailmasõja eelses Tartu ülikoolis viimase ungari keele lektorina.

Béla Kálmáni (1913-1997) kohta on teada, et ta kuulas 1934. aasta sügissemestril Tartu ülikoolis J. Margi lapi keele loenguid ja osales udmurdi keele seminarides. Peale selle käis stipendiaat J. Mägiste liivi keele ja A. Saareste eesti dialektoloogia loengutes (3: 42). Järgmise aasta kevadsemestril käis B. Kálmán J. Margi sürjakomi keele seminaridel ja tõlkis sürjakomi tekste, kuulas J. Mägiste loenguid soome keele häälikuloost ja algsoome häälikuprobleemidest ning A. Saareste loenguid eesti murretest ja morfoloogiast. Eestis oleku ajal avaldas enesetäiendaja neli kirjutist, milles tutvustas Budapesti Jószef Eötvösi kolledžit, Ungari esimesi raamatuid ja sealse keeleuuenduse põhimõtteid. Ungari keeleuuendusest kõneles ta Emakeele Seltsis. Kálmán käis 1934. aastal Petserimaal (Petseri, Vinski, Uusvada). Järgmisel aastal viibis ta Tallinnas, Viljandis, Paistus, Uue-Suislepal (Felix Oinasel külas), Pärnus, Pärli mõisas, Elvas ja Kassemal ning võib-olla ka Narvas. Raamatute vahendusel tutvus ta eesti kirjanduse, ajaloo, etnograafia ja arheoloogiaga (3: 42-44). 
Béla Kálmánist sai pärastpoole Debrecenis Lajos Kossuthi ülikooli soome-ugri õppetooli juhataja ja professor ning Ungari teaduste akadeemia liige. Ta on uurinud ugri keeli, eriti mansi keelt (Forschungsstätten 1975: 152). B. Kálmán on tõlkinud eesti kirjandust ungari keelde, sh Eduard Vilde romaani „Mäeküla piimamees” (1967) ja Anton Hansen Tammsaare jutustusi, samuti XX sajandi teise poole kirjanike teoseid (Palmeos 1974: 422, 423; Bereczki 2011: 278, 279, 283).

Stipendiaat Ö dön Lav ot ha (1914-1972) oli enne Tartusse tulekut lõpetanud Budapesti ülikooli ungari ja ladina keele õpetaja kutsega (Palmeos 1974: 419). Tema huvide ring oli üsna lai. Peale keeleteaduse õppetöö osales ta Gustav Suitsu eesti kirjanduse loengutel ja kuulas Johann Estami loenguid Eesti haridusala korraldusest. Ö. Lavotha osales samuti J. Margi ja A. Saareste õppetöös. Esimese juures tegi ta mordva ja udmurdi keele seminariharjutusi ning õppis lugema sürjakomi tekste. A. Saareste õpetas talle eesti murdeid ja morfoloogiat ning eesti ja läänemeresoome keelte sõnajärge, samuti üldkeeleteadust. Peale selle ammutas Ö. Lavotha teadmisi Paul Ariste üld- ja eksperimentaalfoneetika praktikumides, õppis Mihkel Toomse juures soome ja livviko keelt ning käis vene keele lektori Boris Pravdini tundides. Ungari stipendiaadid õppisid ka eesti keelt. Nii märkis Ö. Lavotha Tartus viibimise lõpul, et ta saab aru kõnekeelest, suudab vestelda, kirjalikult väljenduda ning võib lugeda nii teadus- kui ka ilukirjandust. Stipendiaat tundis suurt huvi ka Eesti maa ja rahva vastu. 1938. aasta mai lõpul tegi ta ringreisi kahes etapis: 1) Tartu-Narva-NarvaJõesuu - Virumaa rannik (Oru, Ontika) - Tallinn-Haapsalu-Lihula-Kuressaare-Vilsandi-Pärnu-Viljandi-Tartu ja 2) Tartu-Petseri-Rõuge-SuurMunamägi-Võru-Pühajärv-Tartu $(3: 15,19)$. Seega tutvus ta nii Põhja-, Lääne- kui ka Lõuna-Eestiga.

Budapesti ülikooli soome-ugri keelte kateedri õppejõuna uuris Lavotha peamiselt ungari keele grammatikat ja õpetas ka eesti keelt. Ödön Lavotha koostas esimese ungarikeelse eesti keele õpiku „Észt nyelvkönyv” („Eesti keele õpik", 1960), mis sisaldab grammatikat, lugemikku ja 7000-sõnalist eesti-ungari sõnastikku. Grammatikaosa avaldati 1973. aastal tõlgitult ka saksa keeles. Lavotha on tõlkinud eesti kirjandust ungari keelde. Esimene teos oli teadaolevalt August Kitzbergi „Libahunt”, mis esimese eesti draamana nägi rambivalgust Budapesti rahvusteatris 1938. aastal. Ö. Lavotha on Anton Hansen Tammsaare romaani „Põrgupõhja uus Vanapagan” (1959) kaastõlkijaid (Bereczki 2011: 283). Samuti vahen- 
das ta Oskar Lutsu „Kevade”, mis ilmus samuti 1959. aastal (Palmeos 1974: 420).

Aastatel 1959-1962 tegutses Ö. Lavotha ungari keele lektorina Helsingi ülikoolis, kus ta avaldas koos Viljo Tervosega „Unkarin oppikirja” („Ungari keele õpik”, 1961). 1962. aastal siirdus ta Lundi, kus koostas koos Csilla Lavothaga „Lärobok i ungerska” („Ungari keele õpik”, 1973)..$^{5}$

Õpetajakandidaat Mag d a H e rg er kuulas Tartus J. Margi loenguid mordva keelest ja sooritas kevadsemestril selles aines eksami, osales mordva keele seminaris ja soome-ugri häälikuloo loengutel. Sama õppejõu juures võttis stipendiaat osa isegi ungari keele häälikuloo kursusest. Ta viibis J. Mägiste läänemeresoome keeleteaduse loengutel, kus anti ülevaade ka indoeuroopa laenudest. Lektor Johannes Voldemar Veski õpetas M. Hergerile eesti keele grammatikat. Lisaks tundis stipendiaat huvi kirjanduse vastu, käies prof G. Suitsu ja mag Johannes Semperi loengutel. M. Herger ei jätnud tegemata ka Eesti ringreisi, viibides Tallinnas, Hiiumaal, Haapsalus, Keila-Joal, Viru põhjarannikul, Narvas, Petseris, Otepääl ja Elvas. Peamiseks sihiks oli stipendiaadil võimalikult hea eesti keele oskuse omandamine. Jõulu ajal käis M. Herger Soomes (3: 36, 40).

Etnograaf doktor Lás z ló (K e s zi -) Ková c s (snd 1908) uuris Eesti Rahva Muuseumis soome-ugri esemete kogu ja eesti põlluharimisriistu. Ta koostas enda jaoks eesti etnograafilise kirjanduse bibliograafia. Samuti tundis ta Tartus huvi museoloogia üldküsimuste vastu, nagu kogumistöö metoodika ja printsiibid ning kogude korraldamise viisid. Eesti paikades reisis ta suhteliselt vähe, käis vaid Petseris ja Petserimaal, Elvas, Kambja ümbruses, samuti Tallinnas (3: 12). L. Kovács sai hiljem tuntuks Ungari materiaalse kultuuri igakülgse uurijana, samuti sealsete esimeste etnograafiafilmide tegijana.

Kaks Ungari stipendiaati polnud seotud rahvusteadustega, mistõttu SUU EK polnud neist eriti vaimustatud. Teoloogia üliõpilane Ján o s K a j o s, kes viibis Eestis Ungari stipendiaatidest kõige kauem (14 kuud), huvitus usuelu kõigist tahkudest, tutvudes Tartu ülikooli usuteaduskonna õppetegevusega, üliõpilaste eluga, kirikute ja kirikuringkondadega, ning õppis eesti keelt (1:34p, 39, 40; 3: 1). Vist matemaatikat õppiva A 1 b e r t Mja zovs zky Tartu-perioodist pole midagi eriti teada. Dokumentides

\footnotetext{
5 Retsensendi täiendus.
} 
kajastub vaid ta tutvumisreis Eestiga marsruudil Tartu-Viljandi-PärnuKuressaare-Vilsandi-Muhu-Haapsalu-Tallinn-Narva-Narva-Jõesuu (3: 25).

\section{Eesti vahetusprofessorid Ungaris}

Tartu ülikoolis õpetasid 1920. aastatest alates ungari keelt välislektorid. Selles ametis tegutsesid enne Teist maailmasõda Elemér Virányi (aastatel 1922-1928), Nils-Herman Lindberg (1930-1931) ning filoloogiadoktori kraadiga Jószef Györke (1931-1936) ja Jenő Fazekas (1937-1940). ${ }^{6}$ Keele omandamise seisukohalt oli väga oluline, et seda õpetasid sünnipärased ungarlased (v.a Nils-Herman Lindberg). Ungari keele õpetamise ajaloost Tartu ülikoolis on andnud ammendava ülevaate Tõnu Seilenthal (2003).

SUU EK kümne tegevusaasta jooksul said Ungaris vahetusprofessoritena (pr professeur déchange) töötada vaid kaks Eesti juhtivat teadlast, komitee liikmed Andrus Saareste ja Julius Mägiste, kumbki kaks semestrit.

Andrus Saareste (1892-1964) tahtis Ungarisse minna juba 1934.-1935. õppeaastal, kuid hilines millegipärast dokumentide esitamisega. Ta süüdistas komitee kaasliikmeid, et talle ei oldud õigel ajal (!) tähtajast teatatud (3: 58). Seepärast sai ta kandideerida järgmiseks õppeaastaks. Ent Ungari jagas vahetusstipendiumi vaheldumisi kord Soomele, kord Eestile, kuid seni oli seda kasutanud üksnes Soome (2: 80). Sedapuhku oligi saabunud Soome kord. Seal esitas stipendiumitaotluse prof Lauri Kettunen. Saanud kuulda, et ka A. Saareste kandideerib, võttis ta oma avalduse aupaklikult tagasi. Ungari saatkond Helsingis tahtis aga järjekorrast kinni pidada ja kuulutas Soomes välja uue konkursi. L. Kettunen nõustus tingimusel, et Eesti saab samal aastal paralleelse võimaluse. Päriselt see siiski nii ei läinud. L. Kettunenile anti täisstipendium kümneks kuuks, kuid A. Saarestele ainult erakorraline stipendium viieks kuuks ja lisaks veel Budapesti ülikooli abiraha üheks kuuks. Peale selle oli A. Saareste Ungaris veel ühe kuu omal kulul.

A. Saareste pidas 1935/1936. õppeaastal Budapestis eesti keele loenguid ja juhatas keeleharjutusi kaks tundi nädalas. Puhuti viibis keelemees väljaspool pealinna, peamiselt Szegedis. Prof A. Saareste tegevusest saaks ehk lähemalt teada Ungari haridusministeeriumi arhiivisäilikutest, mille

${ }^{6}$ Bernard Kangro (1970: 59) on millegipärast jätnud ungari keele lektorite loendis E. Virányi nimetamata, kuigi teisal ( $1 \mathrm{k} 22)$ on teda siiski maininud. 
hulgas peaks leiduma ka vahetusprofessori tööaruanne (3: 31). Peale õppetöö viimistles Saareste Ungaris oma ungari keele oskust, tutvus seal tehtava teadustööga ja asjakohase kirjandusega, lõi kontakte Ungari keeleteadlastega ning tutvustas eesti keeleteaduse saavutusi (3: 49). A. Saareste oli silmapaistev dialektoloog, murdegeograafilise meetodi juurutaja Eestis, kuid Ungaris oli murrete uurimine P. Palmeose (1983: 168) sõnutsi toona veel algjärgus.

SUU EK koosolek kiitis heaks J. Margi 12. veebruari 1936. a kirja Ungari haridusministrile ettepanekuga asutada Ungaris eesti keele lektoraat. Eesti-Ungari kultuurikonventsiooni põhjal see P. Pázmányi ülikoolis loodigi (1: 25p, 29, 33). Lektoriks oli 1936. aasta kevadel, nagu eespool mainitud, üliõpilane Felix Oinas.

Järgmisena õpetas Ungaris eesti keelt vahetusprofessorina Juli u s Mä g i s t e (1900-1978), kes viibis seal 1937.-1938. õppeaastal. Ta õpetas sügissemestril kaks tundi nädalas eesti keelt, kuid kevadsemestril vaid ühe tunni, teise tunni kulutas aga Ungari haridusministeeriumi soovitusel läänemeresoome häälikuloole. Kogu õppetöö toimus ungari keeles. Peale ametliku õppetöö korraldas J. Mägiste oma korteris huvilistele nädalas ühe tunni eestikeelse teksti lugemist. Lisaks esines ta kolmel korral Eestit tutvustava ettekandega, nimelt detsembris Ungari-Eesti seltsi avakoosolekul, veebruaris Eesti iseseisvuspäeva puhul ühes Budapesti keskkoolis ja mais Debreceni ülikoolis. Juunis pidas J. Mägiste Budapesti keeleteaduslikus seltsis ettekande sõnaetümoloogiatest. Samal kuul loeti Ungari raadios ette ta ettekanne Eesti Vabariigi juubeli ja laulupeo puhul. Muul ajal lihvis J. Mägiste oma ungari keele oskust ning vahetas mõtteid Budapesti, Debreceni ja Pécsi keeleteadlastega. Viimati mainitud kohas käis ta 1937. aasta septembris ekskursioonil. J. Mägiste tutvus ka ungari keeleteadusliku kirjanduse ja belletristikaga ning mari keelega. Tagasisõidul avanes keelemehel võimalus käia Berliinis asuvas Ungari teaduslikus instituudis (3: 13). Ungari keele kõnelemise oskus säilis J. Mägistel ka hiljem paguluses (Sköld 2000).

\section{Kokkuvõtteks}

Tartu ülikooli juures 1930. aastatel tegutsenud SUU EK, mille koosseisu kuulusid ülikoolis rahvusteadusi edendavad õppejõud, avaldas rahvusteaduste, eriti soome-ugri keeleteaduse arengule, hõimuliikumise 
süvendamisele ja kultuurikontaktide avardamisele soodsat mõju üliõpilaste ja õppejõude vahetuse korraldamise kaudu. Nii Ungaris kui ka Eestis viibis ühtekokku üheksa vahetusüliõpilast, igal õppeaastal kummaltki maalt üks. Nende hulgas leidub mitu hiljem laiemalt tuntuks saanud teadlast. Võõrsil õppides oli võimalik saada teist laadi teadmisi kui oma kodumaal, tutvuda sugulasrahva eluolu ja kultuuriga, õppida selle riigi keelt, tutvustada oma maa kultuuri, luua isiklikke kontakte edaspidiseks. Suure panuse Ungari-Eesti kultuurisidemete arendamisse andis enne Teist maailmasõda Felix Oinas ungari kirjanduse eesti keelde vahendamisega ja pärast sõda veelgi olulisemal määral Paula Palmeos, kes tegutses 45 aastat ungari keele õppejõuna, tõlkijana ja tõlkijate koolitajana. Alo Raun õpetas ungari keelt ja kirjandust ning uuris hungaroloogilisi küsimusi. Stipendiaatidest on eesti kirjandust ungari keelde vahendanud Béla Kálmán ja Ödön Lavotha. Viimane õpetas ka eesti keelt. Jószef Györke ja Jenő Fazekas töötasid Tartu ülikoolis ungari keele lektoritena. Vahetusprofessoritena käisid Ungaris oma teadmisi jagamas, keeleoskust parandamas, Ungariga tutvumas ja isiklikke kontakte loomas Andrus Saareste ja Julius Mägiste. Kõigil teadusteedel rühkijatel oli võimalus sugulasmaal vajalikku ainest koguda, mida rakendati soovi ja vajaduse korral oma uurimistöös.

\section{Kirjandus ja veebiallikad}

AA = Album Academicum Universitatis Tartuensis 1918-1944. I-III, 1994. Koost. Lauri Lindström, Toomas Hiio, Helina Tamman jt. Tartu.

Aader, Lembit 2007. Helme õpetajad aitasid piirkonnal ärgata. - Sakala 13.10.2007; http://wwx.sakala.ajaleht.ee/300109/laupaev/kodulugu/ 5029170.php (24.02.2012).

Alvre, Paul 1990. Alo Raun - sein Leben und Schaffen. - Linguistica Uralica XXVI (3), 197-201.

Bereczki, Andres 2011. Eesti kirjandus ungari keeles. - Keel ja Kirjandus 3, 277-284.

BN = Tartu Riikliku Ülikooli õppe-teaduskoosseisu biobibliograafia nimestik 1944-1980. 1987. Tallinn: Valgus.

EKL $=$ Eesti kirjarahva leksikon. 1995. Koost. ja toim. Oskar Kruus. Tallinn: Eesti Raamat.

$\mathbf{E T B L}=$ Eesti teaduse biograafiline leksikon. $2(\mathrm{Kj}-\mathrm{M})$, 2005. Peatoim. Karl Siilivask. Teadusajaloo ja Teadusfilosoofia Eesti Ühendus. Tallinn: Eesti Entsüklopeediakirjastus. 
Forschungsstätten $1975=$ Forschungsstätten für Finnougristik in Ungarn. Budapest: Akadémiai kiadó.

Kangro, Bernard 1970. Universitas Tartuensis: Eesti Vabariigi Tartu Ülikool ja üliõpilaskond sõnas ja pildis. Lund: Eesti Kirjanike Kooperatiiv.

Miller 1961 = Arnold Miller [nekroloog]. - Emakeele Seltsi aastaraamat VII (1961). Tallinn, 244-245.

Oinas, Felix 1995. Eluloolisi märkmeid ja mälestusi. - Keel ja Kirjandus 2, $120-128$.

Palmeos 1976 = Palmeos, Pauline. - Keel, mida me harime. Koost. Mart Mäger. Tallinn: Valgus, 204-205.

Palmeos, Paula 1974. Eesti kirjandus ungari tõlkes. - Keel ja Kirjandus 7, 417-424.

Palmeos, Paula 1983. Aastaid sugulaskeelte kütkeis. - Emakeele Seltsi aastaraamat 26/27 (1980/1981). Eesnimedest oskussõnadeni. Tallinn: Eesti Raamat, 165-169.

Palmeos, Paula 1991. Mälestuskilde õpinguteajast. - Keel ja Kirjandus 11, 691-692.

Prozes, Jaak 2012. Hõimuliikumine ja Fenno-Ugria Asutus. - Soome-ugri sõlmed. 2010-2011. Tallinn: Fenno-Ugria, 104-114.

Seilenthal, Tõnu 2003. Ungari keele õpetamine Tartu ülikoolis. - 200 aastat eesti keele ülikooliõpet. Juubelikogumik. (= Tartu Ülikooli eesti keele õppetooli toimetised 25.) Tartu, 306-318.

Sillaots, Liina 2000. Felix Oinas ja Ungari. - Keel ja Kirjandus 6, 419-424.

Sköld, Tryggve 2000. Julius Mägiste Lundis. Mõningaid mälupilte. - Keel ja Kirjandus 12, 886-888.

\section{Arhiivimaterjalid}

Eesti Ajaloo Arhiiv, f 3699, n 1, s 1-3. Soome-Ugri Uurimiste Eesti Komitee. 


\title{
Finno-Ugric exchange students and professors in the 1930s
}

\author{
Enn Ernits
}

The paper deals with Estonian exchange students and professors who studied or taught in Hungary and Hungarian exchange students who continued their studies in Estonia in the 1930s. This introductory study focuses on the history of the Estonian Committee of Finno-Ugric Studies, founded at the University of Tartu. This committee was mainly responsible for the organization of the exchange of students and professors of Estonia and Hungary. In this way the committee contributed to the development of national sciences, particularly Finno-Ugric linguistics, promoted closer ties between Finno-Ugric peoples, and established close cultural contacts. Nine Estonian exchange students visited Hungary and vice versa. Some of them became later well-known scholars. The article discusses their activities abroad and their later achievements, first of all in the sphere of Hungarian-Estonian cultural relations.

Before the Second World War Felix Oinas (1911-2004), later a famous folklorist, translated several novels by Hungarian authors. He was also a lecturer of the Hungarian language. Paula Palmeos (1911-1990) became an important scholar; she taught the Hungarian language at the University of Tartu for 45 years, and she also translated Hungarian fiction. Some of her students became translators and teachers of the Hungarian language. Alo Raun (1905-2004) taught the Hungarian language and literature and studied several Hungarological problems.

Béla Kálmán (1913-1997) and Ödön Lavotha (1914-1972) translation works of Estonian fiction into Hungarian. The latter taught also the Estonian language in Hungary. Jószef Györke (1931-1936) and Jenő Fazekas (1906-1979) worked as lecturers of the Hungarian language at the University of Tartu. Andrus Saareste (1892-1964) and Julius Mägiste (1900-1978), professors of the University of Tartu, visited Hungary as exchange professors.

Keywords: history of national sciences, history of Finno-Ugric linguistic, history of Tartu University, cultural contacts between Hungary and Estonia, promotion of closer ties among Finno-Ugric peoples

Enn Ernits

morfoloogia osakond

Eesti Maaülikool

Kreutzwaldi 62

51014 Tartu

enn.ernits@emu.ee 